\title{
Changing patterns of digital news consumption among Russian journalism students
}

\author{
Elena Vartanova \\ Taras Cherevko \\ Anna Tolokonnikova \\ Denis Dunas \\ Lomonosov Moscow State University, Russia
}

DOI: $10.30547 /$ worldofmedia.1.2019.1

\begin{abstract}
The authors examine features attributed to consumption of news on the Internet by young and active residents of Moscow - students of the Faculty of Journalism at the Lomonosov Moscow State University. The empirical data was based on 'news diaries' filled in by students in the course of a week between February 15, 2016 and February 21, 2016, 40 people in total. Authors analyze users' behavior on the web, specifically their interest in various news resources and links to news publications posted on social websites. The article figures out the contemporary academic approaches to news production, distribution and consumption in the digital environment. The study explores media consumption of young Russians who belong to the 'digital natives' generation. The collected through the empirical research data is proved by the current theoretical approaches to online news consumption process. This article describes the present-day role of the Internet and digital media in the Russian media system to provide context for this analysis.
\end{abstract}

\section{Keywords}

News content, agenda, digital media, Russian media studies, online news consumption, Internet, Russian students, digital natives.

\section{Introduction}

The Internet has dramatically changed the media environment, media industry, and professional practices of the field. In recent decades, the rise of digital media has become the mostly debated issue among media scholars (Flew, 2014;

\footnotetext{
Corresponding author:

Elena Vartanova, Lomonosov Moscow State University, Faculty of Journalism, 9, Mokhovaya st, Moscow, Russia.

Email: evarta@mail.ru
} 
Manovich, 2001). Among questions in this area of inquiry are the nature of new media as compared to the old ones (Kung et al., 2008); the emergence of the new public sphere (Fenton, 2009); changing newsrooms practices and roles of professionals and amateurs; new economics of digital news (Doctor, 2010); and new understanding of information, knowledge and literacy, and digital media consumption (Frau-Meigs, 2007).

The emergence of new, digital media reality in technologically advanced societies is clearly indicative of the formation of a new 'centre of gravity/centre of influence'. What is meant here is the audience, whose activities are concerned with the establishment of new practices in the media environment.

It is essential to raise the question of the future structures, forms and practices of the media, both at the level of society and the individual, because passive consumption of media texts produced by journalists, editors, show business people, advertising experts and public relations professionals is losing its dominant position in the media space. The audience is getting 'active' in terms of text selection, distribution and even production.

Theorizing about news in Western European and North American journalism studies has a long tradition. It focused on the relation of news to the reality, and its possible influence on the audiences (Atwood \& de Beer, 2001; Lasswell, 1927). In the last decades, international scholars have identified basic features of news as a product of journalistic professional activity and analyzed relations between reality and facts. The studies included the process of making/ representing news by newsroom professionals and the construction of reality presented for the audience, including the role of journalists in making news (Lasswell, 1948; McCombs et al., 1997; Shoemaker, 1991; Schudson, 2002; Tuchmann, 1978). One of the most important concepts in the field has been agenda setting (McCombs \& Shaw, 1974) and its subsequent development by P. Shoemaker and S. Reese (Shoemaker \& Reese, 1996). They have found out a number of major influences on media content underlying the role of inertial and external factors, their variety and complexity. The scholars have pointed a multilayer nature of media content production which has been useful for a contemporary understanding of the news gathering, writing, dissemination, and selection by audiences.

However, today the distribution of news in new media is not a vertical, but horizontal process, and not institutional forces but the audience by itself becomes the leading driving force of its dynamics. The key transformation of the media communication process of online news (from the producer to the recipient) is connected with the decentralization of the media system. This essential change in the media landscape in the digital age led to the reconceptualization of news 
in the context of new media (Balmaeva \& Lukina (eds.), 2016; Couldry \& Hepp, 2017; Doctor, 2010; Fenton, 2009; Flew, 2014; Tkacheva et al., 2016a; Tkacheva et al., 2016b (ed.), 2010; Vartanova, 2013).

Both the process of agenda formation and the content structure are transformed (McCombs \& Guo, 2014; Shoemaker \& Reese, 2014; Shoemaker \& Vos, 2009). The global technological revolution inspired scholars to re-consider the concept of news. The particular interest strived from the fact that processes of its production and distribution in a new digital environment involved an increased number of professionals such as journalists, advertisers, PR-specialists and non-professionals, for instance bloggers, Internet and social networks users, who became active in setting news agendas.

Researchers have described new conditions of making, disseminating, and developing news in the digital media (Dunas et al., 2016), analyzed the nature of news provision in Russia and pointed to an increased influence of new media on the national media system (Gureeva, 2015), identified the changed role of audiences in consuming, sourcing, producing and disseminating of news, pointed to growing gaps in generational media cultures (Kulchitskaya, 2014; Vartanova et al., 2014), and examined in diversification of news sources and agendas (Gladkova \& Korobeynikova, 2016; Tolokonnikova \& Cherevko, 2016).

Scholars also have re-considered relations of news producers, journalists and audience, resulting in news production decentralization, de-hierarchization and de-monopolization. For the audience it is easier to bypass journalists as monopolist producers of news and news agendas although new outcomes of the process are both positive (increased speed, sources' accessibility, audience's involvement in the production process) and negative (deskilling, unreliability, manipulation) (Balmaeva \& Lukina, 2016; Lukina, 2010; Viren \& Frolova, 2015).

Together with structural changes, many media companies have changed operations and production. News agencies now directly access audiences providing news on the consumer's first demand, becoming competitors for press and audiovisual media (Vartanova \& Frolova, 2010). The classical model of information agenda has become complemented with the alternative or parallel agenda models, actively involving users' new production and active dissemination (Vartanova, 2014).

\section{The Internet as a news resource in Russia}

Today, Internet penetration in Russia makes up 76\%, running second to Azerbaijan (78\%) among the CIS countries. Yet, this indicator is much lower than the average for Europe, it standing at $80 \%$ or for North America at $88 \%$. 
Thus, the growth potential in Russia is still great ${ }^{2}$. At present, network resources are used regularly by more than half of Russians. According to FOM, 82 m., i.e. $70 \%$ of adults in 2017 accessed the Internet at least once a month, and $72 \mathrm{~m}$., i.e. $61 \%$ visited the Internet daily ${ }^{3}$.

For a long time Moscow led by the number of the Internet users, and though the situation is gradually changing, only Saint Petersburg so far come close. At that, the number of weekly users in Moscow is greater, coming up to over 8 million.

Table 1

\section{Number of Internet users}

\begin{tabular}{|c|c|c|}
\hline Region & Use the Internet once a month & Use of the Internet once a week \\
\hline Russia & 48.4 million $-76 \%$ & 46.7 million $-74 \%$ \\
\hline Moscow & 8.6 million $-80 \%$ & 8.4 million $-78 \%$ \\
\hline St. Petersburg & 3.7 million $-80 \%$ & 3.6 million $-78 \%$ \\
\hline
\end{tabular}

June - August 2017, in millions of people and in \% from population, $12+$

Source: Mediascope / TNS Web Index

The broadband access in the capital is the fastest and the price is among the lowest, while the price of the mobile Internet in Moscow is noticeably higher than in other regions, being costlier only for those who live in the Far East regions ${ }^{4}$. Yet, price notwithstanding, both the mobile and the Internet are quite accessible to Muscovites, considering that earning in Moscow is really high.

${ }^{2}$ Internet world state Internet usage statistics. The Internet big picture. World Internet users and 2017 population stats. - 2017. - Nov. - Available from: www. internetworldstats.com/stats.htm

${ }^{3}$ Internet v Rossii: dynamika proniknovenia. Vesna 2017 [Internet in Russia: penetration dynamics. Spring 2017] // Fond 'Obshchestvennoe mnenie' 2017 [Fund 'Public opinion' 2017] - June. Available from: http://fom.ru/SMI-i-internet/13585

${ }^{4}$ Yandex research Internet development in Russian regions. Spring 2015. Available from: https: //yandex.ru/company research/2015/ya_internet_regions_2015\# vozrastpolzovatelejinterneta 
Devices used for Internet access

\begin{tabular}{|c|c|c|c|c|c|c|}
\hline Region & $\begin{array}{c}\text { Desktop } \\
\text { Computer }\end{array}$ & Laptop & Smartphone & Tablets & $\begin{array}{c}\text { Mobile } \\
\text { Phone }\end{array}$ & $\begin{array}{c}\text { Television } \\
\text { Set }\end{array}$ \\
\hline Russia & $53 \%$ & $49 \%$ & $75 \%$ & $30 \%$ & $6 \%$ & $17 \%$ \\
\hline Moscow & $55 \%$ & $51 \%$ & $78 \%$ & $37 \%$ & $6 \%$ & $16 \%$ \\
\hline $\begin{array}{c}\text { Saint } \\
\text { Petersburg }\end{array}$ & $51 \%$ & $57 \%$ & $78 \%$ & $37 \%$ & $6 \%$ & $15 \%$ \\
\hline
\end{tabular}

June - August 2017, \% of Monthly Reach, 12+

Source: Mediascope / TNS Web Index

On the whole, interest in the mobile Internet is very strong, the number of users accessing the Internet via smartphones and tablets reaching $66 \mathrm{~m}$. in $2017^{5}$. This is especially true of people living in the North Caucasus and Far East since for most people in those areas in no other way for access ${ }^{6}$.

User age is also an important indicator, and it is worth noting that in 2014 over half of the users are younger than 35 . One should also note that the share of older people is growing year on year and in 2017 more than $87 \mathrm{~m}$. of users (54\%) are older than 35 years.

Table 3

Age of Russian Internet users, thousands of people

\begin{tabular}{|c|c|c|c|c|c|c|}
\hline & $\mathbf{1 2 - 1 7}$ & $\mathbf{1 8 - 2 4}$ & $\mathbf{2 5 - 3 4}$ & $\mathbf{3 5 - 4 4}$ & $\mathbf{4 5 - 5 4}$ & $\mathbf{5 5 - 6 4}$ \\
\hline Total & 7440 & 10354 & 22519 & 18363 & 13534 & 10261 \\
\hline Women & 3618 & 5112 & 11406 & 9593 & 7527 & 6045 \\
\hline Men & 3822 & 5242 & 11113 & 8770 & 6007 & 4216 \\
\hline
\end{tabular}

Source: Mediascope / TNS Web Index, March-August

${ }^{5}$ Mediascope data. Available from: http://2017.russianinternetforum.ru/ news/1298/

${ }^{6}$ Yandex research Internet developments in Russian region. Spring 2015 Available from: http://yandex.ru/company/research/2015/ya_internet-regions_2015\# vozrastpolzovatelejinterneta 
The time spent online

\begin{tabular}{|c|c|}
\hline Age group & Average time spent online (minutes per day) \\
\hline $12-17$ & 149 \\
\hline $18-24$ & 133 \\
\hline $25-34$ & 124 \\
\hline $35-44$ & 134 \\
\hline $45-54$ & 151 \\
\hline $55-64$ & 151 \\
\hline
\end{tabular}

Source: Mediascope / TNS Web Index, August

Young people aged 12 to 17 spend online $2 \mathrm{hrs} 29 \mathrm{~min}$. or 149 minutes daily, which is the maximum for all Russia's users, the 18-24 age group coming second with 2 hrs $13 \mathrm{~min}$. or 133 minutes daily ${ }^{7}$. The average time spent online is 2 hrs $18 \mathrm{~min}$. or 138 minutes daily.

To compare, in 2016 average TV viewing time for the audience over 4 years of age in Russia was 4 hrs. 8 min. daily. This is the highest indicator ever for the whole history of TV audience research, which started in $1999^{8}$.

Television thus remains the main means of mass information in Russia but we can note that not all age groups put their trust in this source. Young users aged 18 to 30 trust in news websites more than others.

${ }^{7}$ Dlitelnost prebuvaniya v Internete socialno-demograficheskikh group August 2017, minut v den, 12-14 let // Mediascope [Duration of stay on the Internet of socio-demographic groups] - TNS Web Index. Auditoriya Intrerneta v tslom. Rossiya 100 000+, Moskva, S.Peterburg [Internet audience VCIOM Russia 100 000+, Moscow, S Petersburg]. Tentative survey results. August 2017.

${ }^{8}$ Vartanova, E. L. \& Kolomiyts, V.P. Televidenie v Rossii v 2016 godu. Sostoyanie, tendentsii i perspektivy razvitiya. Otraslevoy doklad [Television in Russia. Status, trends and development prospects. Industry report]. Moscow, 2017, p. 30. 
Which sources of information do you find the most trustworthy?

\begin{tabular}{|c|c|c|c|c|c|c|}
\hline & \multirow[b]{2}{*}{ Russia } & \multirow[b]{2}{*}{ Moscow } & \multicolumn{4}{|c|}{ Age } \\
\hline & & & $\begin{array}{c}18-30 \\
\text { years } \\
\text { old }\end{array}$ & $\begin{array}{c}31-45 \\
\text { years } \\
\text { old }\end{array}$ & $\begin{array}{c}46-60 \\
\text { years } \\
\text { Old }\end{array}$ & $\begin{array}{l}\text { Older } \\
\text { than } 60\end{array}$ \\
\hline Television & $50 \%$ & $33 \%$ & $36 \%$ & $44 \%$ & $59 \%$ & $63 \%$ \\
\hline News websites & $18 \%$ & $17 \%$ & $31 \%$ & $21 \%$ & $14 \%$ & $5 \%$ \\
\hline $\begin{array}{l}\text { Newspapers \& } \\
\text { magazines }\end{array}$ & $8 \%$ & $6 \%$ & $5 \%$ & $5 \%$ & $9 \%$ & $16 \%$ \\
\hline Radio & $8 \%$ & $5 \%$ & $7 \%$ & $7 \%$ & $9 \%$ & $10 \%$ \\
\hline Cannot say & $10 \%$ & $7 \%$ & $2 \%$ & $5 \%$ & $4 \%$ & $6 \%$ \\
\hline
\end{tabular}

Data from FOM (Public Opinion Fund)

Collating the above data with the results of our study we can see that our respondents, Moscow University students, are of interest as a group inasmuch as they are residents of the city with the earliest maximum Internet penetration belong to the young audience that is the most active on the Internet and put trust in it the most. It is not excluded that, in future, the same tendencies will appear in other Russia's regions.

\section{Methodology}

Today it is clear that Internet users increasingly often devise new ways to find, filter, consume, perceive and spread news content. Creating and circulating news have gone far beyond the official media. Common users record events occurring around them on mobile devices and bring them to the public through the social media.

The goal of this study is to find answers to a number of questions that are important in the context of changing media consumption, i.e. which resources active users turn to for new content, how they limit the news flow, what

${ }^{9}$ Weekly poll 'Fomnibus', 28-29th of April, 1-2 of May 2017. 73 subjects of the Russian Federation, 207 settlements, 3000 respondents. Available from: http://fom. ru/SMI-i-internet/13323 
newsbreaks are of the greatest interest to the audience, and, finally, what content in the global network is identified by respondents as news.

The empirical data was based on 'news diaries' completed by the students of Lomonosov Moscow State University's Faculty of Journalism within a period of a week between February, 15th, 2016 and February, 21st, 2016. The respondents were aged from 17 to 23 .

Having sufficiently clear characteristics, this age group has been identified as Millennial Generation (Generation Y), which follows Generation X (Howe \& Strauss, 1991). As multiple researches confirmed, millennials considerably rely on the Internet and social media while searching for news information (Taibi, 2013), which differentiates them from the previous generations. Such peculiarity is most detectable in late millennials, who have become the respondents of the study. Characteristics of their news consumptions, as the authors of the research claim, will allow us to identify some new trends and models of interaction with the media in the near future.

Within the framework of the study, forty students had been completing an electronic questionnaire within one full week, filling in the headlines of all news stories they had been reading throughout the day. They also recorded the source where the material was found (website or social network), the time when they read it, the device used to access the content (stationary computer, laptop, tablet or smartphone) as well as the place where they consumed the information (at home, on their way, at school, at work, etc.). In addition, participants of the survey recorded a sequence of transition from one source to another (See Table 6). 
Sample questionnaire provided to respondents of the study Day 1: Date 15 February 2016

\begin{tabular}{|c|c|c|c|c|c|c|}
\hline Time & $\begin{array}{c}\text { 1st source (what } \\
\text { did you read, } \\
\text { listen, watch?) }\end{array}$ & $\begin{array}{c}\text { Device } \\
\text { (PC, } \\
\text { laptop, } \\
\text { tablet, } \\
\text { phone) }\end{array}$ & $\begin{array}{c}\text { Place (home, } \\
\text { transport, } \\
\text { work, street, } \\
\text { university, } \\
\text { other) }\end{array}$ & $\begin{array}{c}\text { 2nd source } \\
\text { (where did } \\
\text { the first } \\
\text { source lead } \\
\text { you) }\end{array}$ & 3rd & 4th \\
\hline $8: 00$ & $\begin{array}{c}\text { Facebook: a } \\
\text { friend's reaction } \\
\text { (like') to a story } \\
\text { about strikes in } \\
\text { Hong Kong from } \\
\text { The Guardian }\end{array}$ & Laptop & Home & $\begin{array}{c}\text { Looked } \\
\text { through the } \\
\text { article from } \\
\text { The Guardian }\end{array}$ & & \\
\hline $8: 15$ & $\begin{array}{c}\text { Still on Facebook: } \\
\text { Friend's post of } \\
\text { a picture from } \\
\text { Kharkiv }\end{array}$ & Laptop & Home & & & \\
\hline $8: 20$ & $\begin{array}{c}\text { The first case } \\
\text { of Zik fever } \\
\text { in Russia- } \\
\text { interfax.ru }\end{array}$ & Laptop & Home & & & \\
\hline
\end{tabular}

It is important to note that the survey participants mentioned only those materials that they considered as 'news' themselves (not relying on scientific definitions). In this regard, the questionnaire sometimes contained social networks users' personal posts or messages as well as materials of purely entertaining nature: for example, collections of photographs such as ' 2 cats that suddenly became dejected' or ' 25 delicious and beautiful breakfasts you have been dreaming about all week'. Presence of such materials in the general list seems interesting to the authors as it suggests that modern youth's outlook on the news as a genre may differ from the traditional one and opens a new interesting field for research.

Besides news diaries, every respondent submitted a written report with the description of where and how he/she usually consumes information, what sources he/she finds the most topical and trustworthy and how he/she searches for the required information online.

The second stage of the research was connected with analysis of the data received from the respondents. The results of the survey have been processed by the researches manually, without any programs used.

The study focused on consumption of information, which could be categorized as 'news' basing on the criteria of topicality, relevance to the audience, conflict 
potential, human interest element and scale of an event. The material under study included mass media, news agencies headlines, well-known bloggers' posts, and etc. ${ }^{10}$. Such online activities as shopping, video viewing or games were excluded, with the exception of cases when the respondents consumed information that could be classed as 'news'.

All information materials consumed by the respondents were divided in three categories:

1. News read on the information website.

2. News received through special news applications.

3. News read in social networks.

The first category-information website-includes materials that respondents read, viewed or listened on the websites of Russian and foreign online resources, registered as media.

The second category includes materials that students received through mobile applications of various information resources - i.e. through special software that required pre-installation on a mobile device. Such applications particularly included Vesti, Meduza, BBC News as well as various news aggregators (Yandex, News, etc.).

The third category contains materials that users found on the pages of social networks, such as Facebook, VKontakte, Twitter and Instagram. The other social networks were not applied by the participants of the study.

The study lasted for one week, starting on February 15 and ending on February 21, 2016. The time period coincided with the similar surveys of students of other universities.

We are well aware that news consumption and its specificity are hard to interpret and to describe. The given sample and time period cannot fully uncover the model of news consumption by the youth. It is rather an attempt which helps to identify and describe the incipient and transforming ways of news consumption as well as confirm or deny the stereotypes of behaviour of the youth in the information environment. It is clear that journalism students' news consumption differs from that of a greater part of the audience of the same age. We believe that the students in our sample respond quicker to changes in media consumption and that, therefore, their behaviour may be seen as a precursor in the behaviour of the consumer audience on the whole.

${ }^{10}$ News criteria are given according to M. C. Shostak (Shostak, M. (1998). Zhurnalist i ego proizvedenie: Prakticheskoe posobie [Journalist and his work: Practical guide]. Moscow, Gendalf, p. 98). 


\section{Results}

The study shows that the Internet is an extremely important and habitual source of information for all the surveyed. Within the week the respondents browsed 2769 resources. The gap between the frequency of visiting information websites and social networks is not dramatic, though the social networks for news are in the lead. The students learnt 810 news pieces, or $29 \%$ of the total from the social media and 1803 directly from information websites.

Table 7

\section{News consumption from various resources on the Internet Results of poll among 40 students, 2016}

\begin{tabular}{|l|c|c|}
\hline \multicolumn{1}{|c|}{ Type of information resource } & $\begin{array}{c}\text { Number } \\
\text { of scrolled articles }\end{array}$ & $\begin{array}{c}\text { \% from total } \\
\text { number }\end{array}$ \\
\hline Information website & 1803 & $65 \%$ \\
\hline News from news applications & 156 & $6 \%$ \\
\hline Social networks & 810 & $29 \%$ \\
\hline Total number of browsed resources & 2769 & $100 \%$ \\
\hline
\end{tabular}

It came as a surprise that news learnt from news applications of the information websites amounted to a mere $6 \%$. As it turns out, very few respondents use news applications as a source, although they get $66 \%$ of the news content via mobile devices. The respondents' reports on their news consumption show that they consciously reject such services because, in their opinion, these tie up a user with some specific medium, which narrows the news agenda to a certain editorial policy. Most respondents are independent in their news agenda, using filters on VKontakte and on Facebook, turning the social network news into an adaptive news aggregator. 'Even half a year ago I filtered my list of groups and accounts I follow. This allows to find the information you need much faster without focusing on worthless news and similar accounts ${ }^{11}$, - said one of the respondents.

VKontakte ranks the solid first among all sites visited by teenagers, its share being $93 \%{ }^{12}$. This shows that VKontakte is in demand among the

${ }^{11}$ From the essay RU6W23 (where RU - main language, 6 - students number, W - sex, 23 - age).

${ }^{12}$ Issledovanie VKontakte. Portret molodezhi. 2017 [VKontakte survey. Portrait of youth. 2017]. - July. Available from: https://corp.imgsmail.ru/media/files/vkgeneration.pdf 
students generally. Within a week the respondents scrolled 389 articles on VKontakte, which runs to $14 \%$ of consumed news, i.e. twice as high as on Facebook.

The second-ranking Russia's social network Odnoklassniki with a monthly audience of $28 \mathrm{~m} \cdot{ }^{13}$ was not once mentioned by the respondents. This also shows a tendency towards audience segmentation by various social media: today Odnoklassniki attract the older and regional audience. The Brand Analytics data indicate that Moscow is not even on the list of the top-10 regions in terms of the network's geographic spread, and that the share of authors aged 18 to 24 does not exceed $9^{14}$.

The situation with Facebook, which in Russia ranks third in popularity with a monthly audience of $19 \mathrm{~m}$. users ${ }^{15}$, is different. The share of authors aged 17 to 23 on this network does not exceed $9 \%$ and the audience core (68\%) is within the range of 25 to 44 years of age ${ }^{16}$, yet Moscow is the network's main seat, and the number of active authors on it in the capital is by twice higher than in all other regions of the top 10 taken together ${ }^{17}$. Our findings correlate with the statistics: Facebook does enter the list of the Moscow students' news sources but its share is very small due to low demand in this age group.

Meantime some respondents noticed an increasing role of Facebook as a news source. 'I found out that social networks, and Facebook in particular, are the key source of news for me'. Other respondents are ready to leave VKontakte at all. 'As for VKontakte I use it only for studies and a few times a week I look through the posts of my favorite bookstore and the group with soviet photos. But, in general, I can do without it. All business communication goes in Facebook and personal correspondence in messengers such as Telegram ${ }^{18}$. This shift to Facebook takes place mostly in the group of students 21-23 years old.

${ }^{13}$ Top-20 internet proektov. Aug. 2017, Russia 0+, 12-64 years // TNS Web Index: Auditoriya internet-proektov.

${ }^{14}$ Sotsialnie seti v Rossii, zima 2015-2016. Cifry, trendy, prognozy [Social networks in Russia, Winter 2015-2016. Figures, trends, prognoses] / Blog Brand Analytics - January, 2015. Available from: http://blog.br-analytics.ru/socialnye-seti-vrossii-zima-2015-2016-cifry-trendy-prognozy/

${ }^{15}$ Top-20 internet proektov [Top 20 of the Internet projects]. - Aug. 2017, Russia $0+, 12-64$ years // TNS Web Index: Auditoriya internet-proektov [Audience of the Internet projects].

${ }^{16}$ Ibid.

${ }^{17}$ Ibid.

${ }^{18}$ From the essay RU2M21 
The respondents aged 17-20 prefer using VKontakte as a main news source. The younger audience learns half of all news produced by social networks in VKontakte. 'First of all I look through the news feed in VKontakte ${ }^{19}$ '.

Twitter is another significant news source: here the students read 178 news items within the week, which is a fifth of all news they got from the social networks.

The authors of the study were quiet surprised by the relevant data on Twitter. In 2015 the respondents learnt $28 \%$ of news through this micro blog. The situation considerably changed in 2016 . Younger respondents frequently use Twitter whereas respondents of 21-23 years old focus less on it. The respondents from the older group rarely refer to Twitter in their essays and the youngest students find Twitter 'a significant source of information for a journalist and a responsible citizen ${ }^{20}$. That may be explained by the stereotyped journalist behavior formed in 2012-2013. In general the decline of the role of Twitter as a news source correlates with the diminishing role of micro blog in media ${ }^{21}$.

The role of Instagram as a news source is almost negligible, and though the number of subscribers is quite considerable, the students' reports show that hashtags are personal rather that newsworthy.

The respondents mention Telegram as a new source of information in social networks in 2016. But its role wasn't so considerable for that moment and the authors of the present study didn't take in into account. Nevertheless they noticed a growing demand for Telegram. 'As for media consumption in general I refer mostly to social networks - Facebook first and then Instagram, VKontakte, Telegram ${ }^{22}$. The authors are planning to focus more on Telegram in future studies.

${ }^{19}$ From the essay RU8W18

${ }^{20}$ From the essay RU5W19

${ }^{21}$ Sotsial 'nye seti v Rossii, zima 2015-2016. Cifry, trendy, prognozy [Social networks in Russia, winter 2015-2016. Figures, trends, forecasts]. Available from: http://blog. br-analytics.ru/socialnye-seti-v-rossii-zima-2015-2016-cifry-trendy-prognozy/

${ }^{22}$ From the essay RU18M23 
The demand for news in different social networks

Results of poll among 40 students, 2016

\begin{tabular}{|c|c|c|c|}
\hline Social network & $\begin{array}{c}\text { Number of } \\
\text { browsed news }\end{array}$ & Share in social media & $\begin{array}{c}\text { Share in total } \\
\text { number of resources }\end{array}$ \\
\hline VKontakte & 389 & $48 \%$ & $14 \%$ \\
\hline Facebook & 219 & $27 \%$ & $8 \%$ \\
\hline Twitter & 178 & $22 \%$ & $6 \%$ \\
\hline Instagram & 24 & $3 \%$ & $1 \%$ \\
\hline $\begin{array}{c}\text { Total on listed } \\
\text { social networks }\end{array}$ & 810 & $100 \%$ & $29 \%$ \\
\hline
\end{tabular}

Though interest in the social networks is a given, the users do not refuse to consume news directly from the information websites. In the space of week the respondents scrolled 1803 items on the sites which they visited directly, bypassing the social networks. The browsed recourses statistics (see Table ) and text topics show that the users in most cases browsed the trustworthy media resources in search of quality content (see Table 9).

The list of the most popular sites includes the Internet media such as Lenta. ru, Gazeta.ru, Meduza, etc., electronic resources of the print media Izvestia, Kommersnt, Russkiy Reporter among these, and sites of such news agencies as RIA Novosti, Interfax, Newsru.com. The latter attracted the respondents as the sources of the latest news updates. The top 10 also included the sites of such TV channels as LifeNews, Dozhd', and Russia Today which respondents visited for videos. 
Top 10 of news resources on the Internet

Results of poll among 40 students, 2016

\begin{tabular}{|c|c|c|}
\hline $\mathbf{N}$ & Name of the resource & Number of visits \\
\hline 1 & Kommersant & 176 \\
\hline 2 & Meduza & 105 \\
\hline 3 & Izvestia & 83 \\
\hline 4 & Interfax & 67 \\
\hline 5 & RIA Novosti & 59 \\
\hline 6 & Newsru.com & 30 \\
\hline 7 & Lenta.ru & 29 \\
\hline 8 & RBC & 24 \\
\hline 9 & Gazeta.ru & 18 \\
\hline 10 & Dozhd' & 16 \\
\hline
\end{tabular}

The users clearly preferred professional media content, and as is the case for the networks, many users visited one and the same resources regularly to trace the latest events.

The list of the sites which the users visited from the links on the social networks did not remain unchanged (see Table 10). Kommersant, for instance, moved downward while Gazeta.ru rose to the first position. RIA Novosti led in redirections from the social networks while all other news agencies aroused no interest whatever of the respondents in the social media. This may probably be explained by the low activity of these news agencies in the social networks. In this sense, Meduza demonstrates stability and the users saw as favoured both the resource itself and links to it on the social networks. It is evident that the alternative content media aroused greater interest of the respondents when they saw links to these on the social media. 
Top 10 news resources to which users are redirected from social networks Results of poll among 40 students, 2016

\begin{tabular}{|c|l|c|}
\hline $\mathbf{N}$ & \multicolumn{1}{|c|}{ Name of the resource } & $\begin{array}{c}\text { Number of redirections from } \\
\text { social networks } \\
\text { to the resource }\end{array}$ \\
\hline 1 & Gazeta.ru & 136 \\
\hline 2 & RIA Novosti & 104 \\
\hline 3 & Meduza & 94 \\
\hline 4 & Dozhd, Lentach, Rossiyskaya gazeta & 76 \\
\hline 5 & The Village & 56 \\
\hline 6 & Iod, RT, Tjournal & 44 \\
\hline 7 & Bumaga, Life News & 40 \\
\hline 8 & Kommersant & 32 \\
\hline 9 & Snob & 28 \\
\hline 10 & Echo Moskvy & 12 \\
\hline
\end{tabular}

Analysing the news diaries, the authors of the present study found that when the users searched for information on some event, they often did not confine themselves to visiting a single resource but continued navigation. In some cases the respondents wanted to follow some further developments and in others their interest was captured by some irrelevant headline and they went over to something else. In this connection, we tried to see the role of hyperlinks and how often the respondents use these. We denoted this phenomenon as news consumption depth.

The data show that every second scrolled news (59\%) motivates the user to continue information consumption on the Internet. Redirections most often (67\%) occur from links on the social networks. The 3rd redirection to get more information on an event occurred in $15 \%$ of the cases. Only $2 \%$ of the news pieces browsed on the social networks motivate the users to read at least three pieces on the outside resources. At the same time, most respondents, having studied the only article that took their attention come back to the social networks. 


\section{Numbers of users' redirections from one resource to another by clicking on a link}

\begin{tabular}{|c|c|c|c|c|}
\hline & $\begin{array}{c}\text { Number of } \\
\text { direct } \\
\text { visits }\end{array}$ & $\begin{array}{c}\text { Number } \\
\text { of } \\
\text { redirections } \\
\text { to 2nd } \\
\text { resource } \\
\text { from } \\
\text { the 1st one }\end{array}$ & $\begin{array}{c}\text { Number } \\
\text { of redirections } \\
\text { to 3d resource } \\
\text { from the links } \\
\text { on the 2nd one }\end{array}$ & $\begin{array}{c}\text { Number } \\
\text { of redirections } \\
\text { to 4th } \\
\text { resource from } \\
\text { the links on } \\
\text { the 3rd one }\end{array}$ \\
\hline Websites & 607 & 343 & 103 & 3 \\
\hline $\begin{array}{c}\text { News from news } \\
\text { applications* }\end{array}$ & 139 & 17 & - & - \\
\hline News VKontakte & 332 & 230 & 67 & 17 \\
\hline News Facebook & 165 & 132 & 33 & - \\
\hline News Twitter & 170 & 109 & - & - \\
\hline News Instagram & 59 & 15 & 7 & - \\
\hline
\end{tabular}

The situation with the websites is similar. Having scrolled an article on some resource, the third of the users (57\%) click on links to further stories elaborating on the initial news. Then every third of the remainder clicks on the third link, and then only $3 \%$ of these clicks on the fourth, which is done by a mere $0.5 \%$ of those who read the initial news. We believe that this phenomenon deserves a thorough examination and the results will be covered in our papers to follow.

Our analysis of the news consumption depth indicates that the respondents show interest not so much in certain news resources as in certain events, material or headlines. After they had scrolled some text, the users showed no intention to actively consume other content of the same medium, browse additional information, or consistently browse other resources via redirections. They lost interest in the initial subject and either formulated a new query or returned to the social networks. Sometimes they simply stopped media consumption. At the same time, it is obvious the information agenda of the social networks attracts attention of the respondents and not infrequently stimulates deep news consumption.

And now the authors of the present study should stop on devices the students use for monitoring news as they have a great impact on the depth of news consumption. The authors saw that mobile phone doesn't allow getting complete news content. Smartphone users rarely pass to other links while 
they look through the news feed. 'I usually monitor headlines and leads on my phone and don't follow a link to read the news ${ }^{23}$. The reason for that may the inconvenience to switch between tabs on smartphone.

The respondents give priority to smartphones when they consume news content. 'I don't almost use the tablet or laptop to get news. I choose them for watching movies or writing and editing texts ${ }^{24}$. Meanwhile students of 21-23 years who may be already employed more often use laptops to look through news content in the working place. 'I mostly use my phone but when I work I read news on my laptop ${ }^{25}$.

The authors of the study point out that the respondents get much news outside the home. Two areas can be clearly indicated - during studies and en route. There's a curious observation - en route that takes less time than studies students get comparable amount of news. Students say they continuously consume information the biggest part of which is news while using public transport. 'When I go somewhere I always log in social networks and look through news feedback ${ }^{26}$.

According to our findings news consumption depth to a great extent correlates with a news theme. There were some themes that called for several redirections on the part of the respondents to help them understand what was going on and get additional information. At the same time, some themes generated interest limited to reading a lead or a main news item. The news diaries have helped to identify the themes that generated greater interest of the audience, these being the international events (Ukraine / Syria / Migrants), emergency situations, laws/bills.

Many respondents confessed in their reports to getting tired of the news on Ukraine and Syria and stated that they tried to avoid such news and did not respond to the corresponding headlines. Yet, these respondents' diaries testified to the contrary, wing that the topics relating to Ukraine and Syria amounted to $12 \%$ of all the themes. In this connection, the authors believe that, despite the claim of being 'tired' of the international themes, the respondents cannot break away from the information field and change the news consumption model. We intend to continue with the examination of this phenomenon.

As we have found out, the number of direct visits to Facebook and Twitter is close but the user goals are different. To illustrate, the respondents used Twitter almost twice as often to monitor the hot news, the figures being 59\% against

\footnotetext{
${ }^{23}$ From the essay RU14W22

${ }^{24}$ From the essay RU18W18

${ }^{25}$ From the essay RU13W22

${ }^{26}$ From the essay RU12W22
} 
Facebook's 31\%. On the other hand, those who preferred Facebook were more interested in the political content than the Twitter users with $32 \%$ and $25 \%$ respectively.

The survey identified Twitter as the promptest information source and as a kind of regulator of the news agenda which the users may control. Subscription to correspondents or news companies enables the service subscribers to follow events online, thus $67 \%$ of the Twitter users were aware of every second news reason among the latest news topics. This is by $10 \%$ more than that among the Facebook users. Together with the biggest world media, Facebook today tends towards integration of the professional media content into feed readers.

Despite quiet an active news consumption and interest in various kinds of news content some respondents have observed that they get tired of unfiltered news flow and they seek to filter their news feed. These are mostly students of 21-23 years old. Some students noted in their essays: 'It's great to know all the news on spot but sometimes I want to get nothing, switch off and not read any news ${ }^{27}$. Others are able to control their consumption. 'I select news. I don't choose content and authors because I need to read it. Instead I prefer content that interests $\mathrm{me}^{28}$.

\section{Conclusion}

News consumption by the users on the Internet is practically permanent, with comparatively short breaks for sleep. It goes down insignificantly on days off and holidays. This means that the new media face a task of supplying news content round-the-clock for seven days a week to meet the demand of today's audience. Today, consumers actively use the social networks as news resources. In the period under study the respondents read more news on these resources than on the mass media websites. VKontakte is the main news provider for the given audience, Twitter lagging far behind. In terms of total news consumption, the role of other social media is rather small, demand for these on the part of Russian consumers notwithstanding.

The professional media websites such as Kommersant, Gazeta.ru, Meduza etc. are the most popular news resources on the Internet. This can be seen from the number of direct visits and redirections from the social networks. The audience's interest in user content on the Internet cannot so far replace the need for quality information, which, in a new environment, is characterized by timeliness, reliability, and, not infrequently, explanation. Online news consumers take an

\footnotetext{
${ }^{27}$ From the essay RU2M21

${ }^{28}$ From the essay RU14M22
} 
active stand; they are self-sufficient in navigating the information flow and are reluctant to turn aside from the planned route. Browsed material stimulated them to click on the link no more than twice. Clicking on the 3rd link was a rarity.

The social networks enable the audience to consume news as a background activity and thus constantly control the agenda. The news consumers are rather active in visiting the news resources to read what they need and then come back to their own pages using them to monitor news. The respondents often form their own news flow in the social media and seldom visit the official media websites. These are of less interest and even the most popular of these are visited only two or three times a day, and, in most cases, redirections are meant to read some definite material rather than to see the whole picture of the day.

In many respects a modern citizen in a digital society - as a professional, consumer, or member of a community - becomes crucially dependent on digital media. In this context a hypothesis that social networks are central for media consumption of audiences should be further elaborated. The fact that social media create personal news agendas based on individual preferences and news demand, changes not only the production and distribution of news by professional news rooms, but also the traditional theoretic understanding of the agenda setting process, its players, filters and barriers.

However, we should not overestimate the impact of social networks, if we are talking about students - future journalists. They prefer professional news sources more than social networks ( $65 \%$ vs. $29 \%$ ), and they address them regularly, not only occasionally, they recheck news found on social networks on official news sources, including redirecting to the original source (redirections occur most often from links on the social networks $-67 \%$ ), they demonstrate a critical and conscious type of media consumption - more reminiscent of professionally oriented. The phenomenon noted by us - consumption depth - proves the respondents' desire for qualitative surfing and navigation on the internet, not just the thematic expansion of the individual agenda, but its qualitative deepening (every second respondent scrolled news, 59\% continued to consume the news on the Internet further). Still later most of the users returned to the agenda, proposed by the social network algorithm. So the role of social network as the initial provider of the agenda is unquestionable.

Thus, the participants of the study demonstrated the independence and criticality in choosing the ways of searching for the required information. Students were able to navigate fluently in the search engines, in information resources of network communities, but sometimes they needed a considerable amount of time to search and process the data they found. They are characterized 
by a sufficient level of awareness of the meaning and content of the information found and processed and a low level of emotional and cognitive involvement in the virtual space.

Young people turned to professional news sites for information, which indicates the increase in cognitive and activating motives of media consumption, demonstrates criticality in relation to information provided in the media. This allows us to state that students consume media primarily as a source of information. This structure of motivation of media consumption allows us to speak about the mature position of students in relation to mass communication and information.

Thus, not only the level of maturity of students is reflected, but also the character of the activity leading for a given age - educational and professional. Students face the challenge of expanding and deepening their own knowledge, in the solution of which they resort to the use of media sources. They have a sufficient level of knowledge, skills, which contribute to good orientation in the surrounding media space, proves that they spend time on this type of activity productively.

Today, for a modern individual, interaction with the mass media is a certain way, a life style. He is able to do several things at the same time, while quickly moving from one goal to another. Depending on the various forms of the transmission of meanings, media is allowed to build communication practices, such as business, corporate, political, civil, interpersonal ones.

\section{$* * *$}

Of course, the method of self-report, applied in this study, has significant limitations. First, of all, respondents mentioned only those materials, which they considered as necessary themselves; therefore, it's highly likely that the questionnaires present a picture of 'standard' media consumption, as participants saw it. Some materials could have been deliberately excluded from the list by respondents.

Secondly, due to a great volume of information consumed by the modern youth, it is hardly possible to record all the materials read in the news diary. It became obvious that the questionnaires reflected only a part of publications, which respondents identified as separate information material posted on web page, where they made a targeted transition. However, as follows from the essay, process of news consumption through smartphones often occurs in the 'background mode', making it hard for the respondents to notice that they consume informational content along with personal messages in social networks. This aspect clearly requires that the authors 
conduct a detailed research of this problem and look for a solution of it in further in-depth studies on the media consumption by young people. At the same time, for the primary probing, presented in this article, the authors consider the method of self-report as acceptable and appropriate, since it allows making a general idea of the characteristics of media consumption of selected group of respondents and allows identifying the key media resources for it.

\section{References}

ATWOOD, R. \& DE BEER, A. (2001). The roots of academic news research: Tobias Peuser's De relationibus movellis. Journalism Studies, 2(4), pp. 485-496.

BALMAEVA, S. \& LUKINA, M. (eds.) (2016). Kak novye media izmenili zhurnalistiku. 2012-2016. [How new media changed journalism. 201-2016]. Ekaterinburg, Humanitarian University.

BOURDIEU, P. (2002). On television and journalism. Moscow, Fund for scientific research 'Pragmatics of culture', Institute of experimental sociology.

CHEREVKO, T., DUNAS, D. \& TOLOKONNIKOVA, A. (2018). Novosti v usloviyah internetizacii: Analiz novostnogo potrebleniya studentov [News in the networked era: News consumption habits of Moscow students]. Moscow University Journalism Bulletin, 1, pp. 3-25. DOI: 10.30547/vestnik.journ.1.2018.325

COULDRY, N. \& HEPP, A. (2017). The mediated construction of reality. Cambridge, Polity Press.

DIAKOVA, E. (2003). Massovaia politicheskaia kommunikatciia $\mathrm{v}$ teorii ustanovleniia povestki dnia: Ot effekta k protcessu [Mass political communication in the theory of agenda setting: From the effect of the process]. Polis, 3, pp. 109119. DOI: https://doi.org/10.17976/jpps/2003.03.11

DOCTOR, K. (2010). Newsonomics: Twelve trends that will shape the news you get. New York, St-Martins Press.

DUNAS, D., GUREEVA, A., TKACHEVA, N. \& VARTANOV, S. (2016). K voprosu o teoreticheskom ponimanii novostei $\mathrm{v}$ tcifrovuiu epokhu: Transformatciia struktury, sil vliianiia, zhiznennogo tcikla [On the question of the theoretical understanding of news in the digital era: The transformation of the structure, the influence of the forces and the life cycle]. Moscow University Journalism Bulletin, 3, pp. 3-16.

FAPMC (2016). Televidenije v Rossii. Sostojaniye, tendencii i perspektivy razvitija [Television in Russia. Current state, trends and prospects for development]. Report of the Federal Agency for Press and Mass Communications. Available from: http://fapmc.ru/rospechat/activities/reports/2016/television-in-russia.html 
FENTON, N. (2009). New media, old news: Journalism and democracy in the digital age. London, Sage.

FLEW, T. (2014). New media. Oxford, Oxford University Press.

FRAU-MEIGS, D. (2007). Media education. A kit for teachers, students, parents and professionals. Paris, UNESCO.

GLADKOVA, A. \& KOROBEYNIKOVA, K. (2016). Examining the public's exposure to reports about ethnic groups in mainstream Russian media. Psychology in Russia: State of the Art, 9(1), pp. 164-177.

GUREEVA, A. (2015). Sotsialnye seti v sostave sovremennykh mediakommunikatsij rossijskogo vuza [Social networks in the structure of modern media communications of Russian higher schools]. Moscow University Journalism Bulletin, 6, pp. 146-160.

HOWE, N. \& STRAUSS, W. (1991). Generations: The history of America's future, 1584 to 2069. New York, William Morrow.

KULCHITSKAYA, D. (2014). Psychological prerequisites and effects of using multimedia content in the mass media. Psychology in Russia: State of the Art, 7(4), pp. 88-97.

KUNG, L., PICARD, R. \& TOWSE, R. (2008). The Internet and the mass media. London, Sage.

LASSWELL, H. (1927). Propaganda techniques in the First World War. New York, Alfred Knopf.

LASSWELL, H. (1948). The structure and function of communication in society. In: L. Bryson, The Communication of ideas. New York, Harper.

MANOVICH, L. (2001). The language of new media. New York, MIT Press.

MCCOMBS, M. E. \& GUO, L. (2014). Agenda-setting influence of the media in the public sphere. In: R. S. Fortner \& P. M. Fackler, The Handbook of media and mass communication theory. West Sussex, UK, John Wiley \& Sons, pp. 249-268.

MCCOMBS, M. E. \& SHAW, D. L. (1972). The agenda-setting function of mass media. Public Opinion Quarterly, 36, pp. 176-187.

MCCOMBS, M. E., SHAW, D. L. \& WEAVER, D. (1997). Communication and democracy: Exploring the intellectual frontiers in agenda-setting theory. New York, Lawrence Eribaum Associates.

MIRONOVA, M. (2015). Provintcialnye SMI v reitinge Yandeks.Novosti [Regional media in the rating of Yandeks.Novosti]. Chelyabinsk State University Philology and Art Bulletin, 5 (360), Vol. 94, pp. 325-329.

SCHUDSON, M. (2002). The sociology of news. New York, Norton.

SHAW, D. \& MCCOMBS, M. E. (1974). The emergence of American political issues: The agenda-setting function of the press. St. Paul, Minn, West.

SHOEMAKER, P. \& VOS, Y. (2009). Gatekeeping theory. London, Routledge. 
SHOEMAKER, P. \& REESE, S. (1996). Mediating the message: Theories of influences on mass media content. USA, Longman.

SHOEMAKER, P. \& REESE, S. (2014). Mediating the message in the stcentury: A media sociology perspective. New York, Routledge.

SHOEMAKER, P. (1991). Gatekeeping. Thousand Oaks, CA, Sage.

SOLDATOVA, G. (2013). Cifrovaja kompetentnost' podrostkov i roditelej: rezul'taty vserossijskogo issledovanija. [Digital competence of children and parents: Results of the all-Russia study]. Moscow, Internet Development Fund.

TAIBI, C. (2013). Pew: Young people 'graze' for news, old people stick to TV and print. The Huffington Post, 16th October, 2013. Available from: http://www. huffingtonpost.com/2013/10/16/pew-news-consumers-young-old_n_4109929. html

TUCHMAN, G. (1978). Making news: A study in the contraction of reality. New York, Free Press.

VARTANOVA, E. (2014). Media in digital society: Challenges of active audience. Global Media Journal - Slovenske vydanie/Slovak Edition, 2, pp. 16-27.

VARTANOVA, E., TOLOKONNIKOVA, A. \& CHEREVKO, T. (2014). The information security of children: Self-regulatory approaches. Psychology in Russia: State of the Art, 7(3), pp. 136-145.

VIREN, G. \& FROLOVA, T. (2015). Informatcionnye agentstva: Kak sozdaiutsia novosti [News agencies: How news is made]. Moscow, Aspect Press. 